\title{
The effects of a four-week intensive scoliosis- specific exercise programme on patient-reported quality of life in adult subjects with idiopathic scoliosis: a $>3$ years follow-up study
}

\author{
Erika Maude $^{1 *}$, Jason Black', David Glynn², Juliet Mayes ${ }^{1}$, Christine Pilcher ${ }^{1}$, Charlie Meekings ${ }^{1}$ \\ From 11th International Conference on Conservative Management of Spinal Deformities - SOSORT 2014 \\ Annual Meeting \\ Wiesbaden, Germany. 8-10 May 2014
}

\section{Background}

Health-related quality of life (QoL) is often reduced in adults with scoliosis [1]; therefore it is essential for any treatment they receive to address this. The Scoliosis Research Society-30 (SRS-30) questionnaire is a widely used [2], specific instrument to measure clinical outcomes in patients with scoliosis [3].

\begin{abstract}
Aim
The aim of this observational case series is to investigate previous results on whether a four-week intensive scoliosis-specific exercise programme improves patientreported QoL in subjects with idiopathic scoliosis, by using a much larger number of participants, longer follow-up and only including adult patients.
\end{abstract}

\section{Design/methods}

The data set was composed of 731 adult patients (578 females and 153 males) with idiopathic scoliosis and a mean age of 33 years (range 18-64 years, SD 14.68) who were treated with a four-week intensive course of scoliosis-specific physiotherapy (the ScolioGold method) between 2006 and 2013. All patients were asked to rate their QoL on their first day of treatment, at the end of their four-week course and at any subsequent check-up appointments they attended, using a modified version of the SRS-30 questionnaire (replacing 'surgery' with 'treatment'). Each subset, which was analysed from the original data set, was determined by having data pretreatment and at the relevant time point.

\section{Results}

In the cohort analysed before and after treatment $(\mathrm{n}=512)$, mean total SRS-30 score increased from 3.19 (SD 0.58) to 3.60 (SD 0.47). For the cohort analysed before treatment and at $>3$ years $(n=64)$, SRS-30 score increased from 3.23 (SD 0.58) to 3.69 (SD 0.44). Increases in QoL compared to pre-treatment results were found to be statistically significant $(\mathrm{p}=<0.05$ using a pairwise t-test, corrected for multiple comparisons) at all time points investigated (post-treatment, 1 year, 3 years, $>3$ years). This was reflected in all subscales, with the exception of function.

\section{Conclusion}

These results show the positive effect of intensive exercise methods, such as ScolioGold, on adult patients' QoL and add to the evidence for scoliosis-specific physiotherapy. However, future research is required to establish the effects of treatment on those adults who elect not to return for check-up appointments, including those who may, or may not, have discontinued treatment.

\section{Authors' details}

'Scoliosis SOS Clinic, London, UK. 'Independent Statistician, London, UK.

Published: 4 December 2014

'Scoliosis SOS Clinic, London, UK

Full list of author information is available at the end of the article 


\section{References}

1. Tones MJ, Moss ND, Polly DW: A Review of Quality of Life and

Psychosocial Issues in Scoliosis. Spine 2006, 31(26):3027-3038.

2. Chapman JR, Dettori JR, Norvell DC: Spine Classifications and Severity

Measures. Thieme or AO Publishing, New York or Switzerland; 2009.

3. Yilmaz H, Kuru T: A Comparison of the Results of SRS-30 questionnaire in

Scoliosis Patients Treated Surgically or Conservatively. Scoliosis 2012, 7(Suppl 1):P15.

doi:10.1186/1748-7161-9-S1-069

Cite this article as: Maude et al:: The effects of a four-week intensive scoliosis-specific exercise programme on patient-reported quality of life in adult subjects with idiopathic scoliosis: a $>3$ years follow-up study. Scoliosis 2014 9(Suppl 1):069.

\section{Submit your next manuscript to BioMed Central} and take full advantage of:

- Convenient online submission

- Thorough peer review

- No space constraints or color figure charges

- Immediate publication on acceptance

- Inclusion in PubMed, CAS, Scopus and Google Scholar

- Research which is freely available for redistribution

Submit your manuscript at www.biomedcentral.com/submit 